\title{
ESTUDO DE BIOFILMES E O POTENCIAL DE CORROSÃO EM AÇO INOXIDÁVEL EM ÁGUAS MARINHAS
}

\author{
Brunela dos Santos Neves - brunelasn@ gmail.com \\ Instituto Federal de Educação, Ciência e Tecnologia do Espírito Santo - Campus \\ Vitória
}

Adriana Marcia Nicolau Korres - adrianak@ifes.edu.br Instituto Federal de Educação, Ciência e Tecnologia do Espírito Santo - Campus Vitória

Viviane Azambuja Favre-Nicolin - viviane@ifes.edu.br Instituto Federal de Educação, Ciência e Tecnologia do Espírito Santo - Campus Vitória 


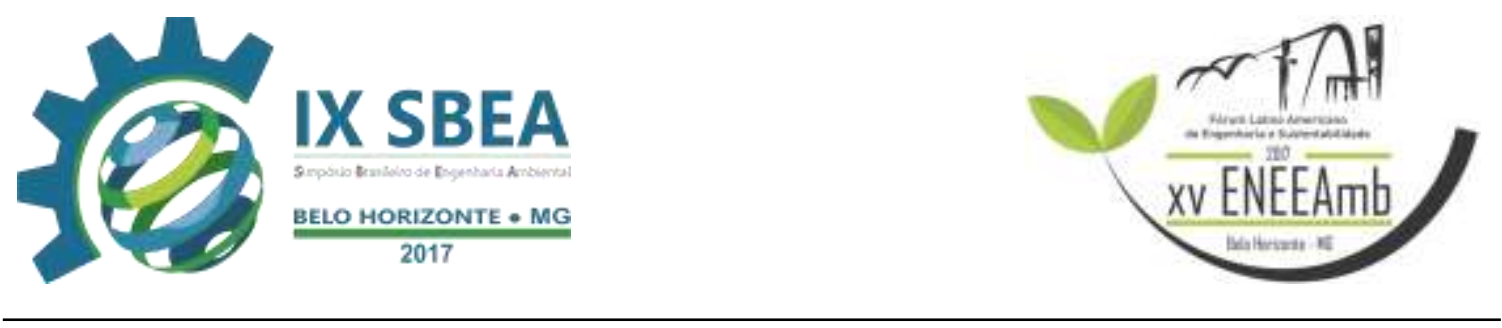

\section{RESUMO}

Os biofilmes são pequenos ecossistemas complexos e dinâmicos, formados por microrganismos envolvidos em uma matriz de polímeros orgânicos aderidos a uma superfície. Microrganismos estruturados em biofilmes demonstram uma preferência pelo processo de adesão em diversas superfícies, incluindo aço inoxidável. O ambiente marinho é um ambiente propício para associação de microrganismos devido à velocidade das ondas, temperatura do ambiente, potencial eletroquímico de substratos metálicos imersos na água do mar e diversos outros fatores que propiciam essa interação. O presente trabalho tem como objetivo estudar o biofilme e o potencial de corrosão em aços inoxidáveis AISI 316 imersos por 40 dias em águas das praias da Ilha do Boi em Vitoria, ES e Manguinhos na Serra, ES. O estudo incluiu a avaliação do número de unidades formadoras de colônias por $\mathrm{cm}^{2}\left(\mathrm{UFC} / \mathrm{cm}^{2}\right)$ na superfície dos cupons de aço, a caracterização morfológica, determinação de coliformes totais e Escherichia coli e pela perda de massa do material em estudo. Os resultados mostraram um maior número de $\mathrm{UFC} / \mathrm{cm}^{2}$ na contagem global de microrganismos aeróbios mesófilos heterotróficos em aços imersos na água de Manguinhos, observando a presença de cianobactérias somente nesse ambiente. Estas foram ausentes na superfície dos aços imersos na água da Ilha do Boi, possivelmente pela predominância de fungos. O estudo de biofilme no aço inoxidável em ambientes marinhos se torna importante devido à dinâmica de formação e interação dos mesmos com o meio de estudo, podendo comprometer a balneabilidade da água do mar como também o descarte indevido do material danificado pela corrosão, gerando um grande acúmulo de sucata.

Palavras-chave: Biofilmes, Corrosão, Aço Inoxidável, Água Marinha.

\section{INTRODUÇÃO/OBJETIVO}

O ambiente marinho é o mais corrosivo de todos os meios naturais e compreende desde a atmosfera envolvida com sal do mar até regiões mais profundas do oceano com o lodo no fundo do mar. Os componentes e estruturas que estão normalmente expostos aos meios marinhos são, por exemplo, as bombas e tubulações de água do mar, navios, submarinos, cais, estacas e plataformas de petróleo (PONTE, 2003). 


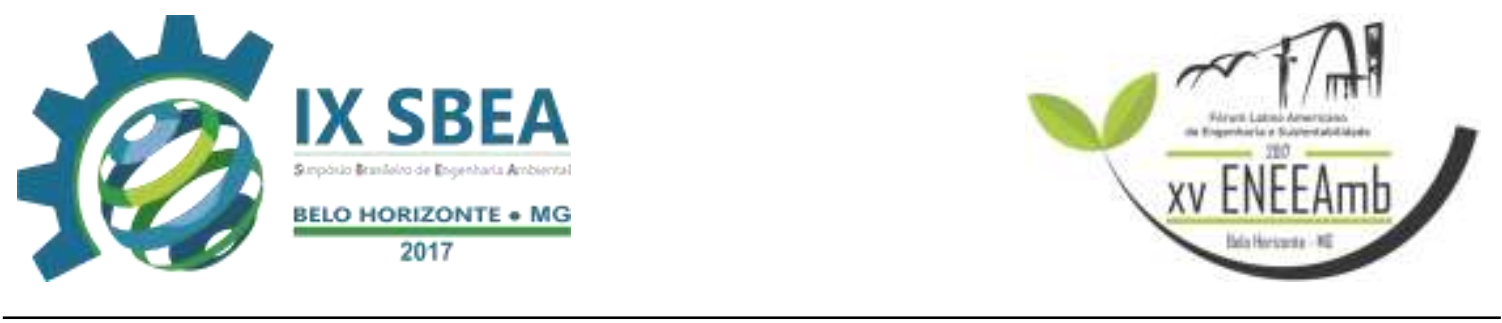

Os biofilmes são pequenos ecossistemas complexos e dinâmicos, formados por microrganismos envolvidos em uma matriz de polímeros orgânicos aderidos a uma superfície, configurando um modo protegido de desenvolvimento microbiano mediante as situações hostis. Microrganismos estruturados em biofilme demonstram uma preferência pelo processo de adesão em diversas superfícies inanimadas, incluindo aço inoxidável (RECH et al., 2013).

Frequentemente, tem sido observado danos causados em estruturas que estão expostas a ambientes marinhos devido à corrosão e a bioincrustação, além do impacto ambiental causado e prejuízos às espécies marinhas (MENEZES, 2012). Dependendo do ponto de vista, os biofilmes podem ser benéficos ou nocivos, daí a necessidade de estudar sua formação nesse ambiente como um meio de determinação da resistência do mesmo, com o intuito de prevenir danos e proteger o material constituinte de estruturas instaladas em ambientes marinhos.

Estima-se que o Brasil direciona cerca de 3,5\% de seu Produto Interno Bruto (PIB) na busca de alternativas para contenção e reposição de materiais deteriorados. Dados também apontam que $25 \%$ da produção anual de aço do país são destinados somente à substituição das estruturas danificadas pela corrosão. Outro problema é que o descarte indevido do material danificado gera um grande acúmulo de sucata (MELLO; ÁVILA; SILVA, 2015).

À vista disso, justifica-se o estudo da comunidade microbiana em superfície de aço por números e a perda de massa do material exposto à corrosão, o que pode esclarecer sobre a formação de biofilmes e possíveis danos associados à corrosão da superfície do aço imersos em águas marinhas.

\section{METODOLOGIA}

\subsection{AMOSTRAGEM DE ÁGUA MARINHA}

As amostras de água foram coletadas semanalmente (sempre nas mesmas praias) durante 40 dias com o uso de bombonas de 10L cada. As praias de coleta foram Praia Grande, localizada na Ilha do Boi, Vitória, ES (figura 1) e a Praia da Enseada, localizada em Manguinhos, Serra, ES (figura 2). 


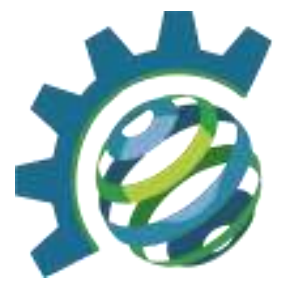

A Ilha do Boi está localizada entre os portos de Vitória e Tubarão, importantes locais de passagem de navios e embarcações. Manguinhos está localizada no município da Serra, que se situa fora da área portuária.

Figura 1 - Mapa da localização da Ilha do Boi (Vitória - ES)

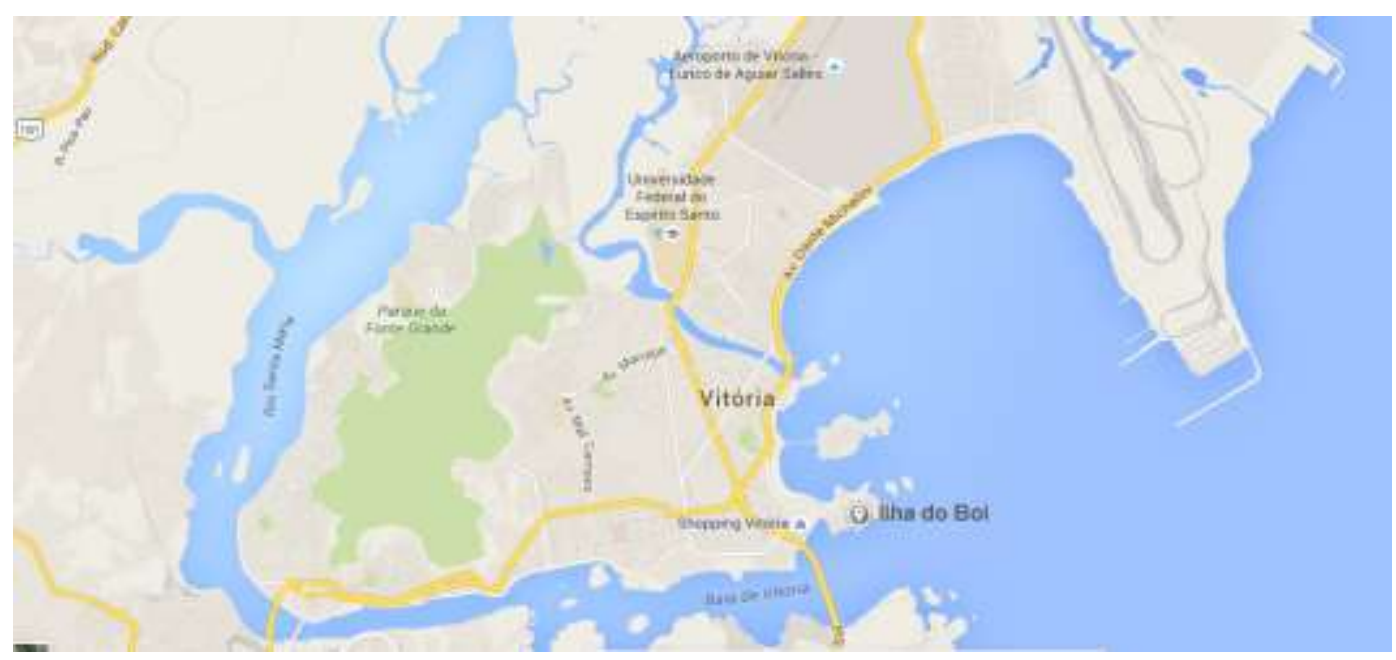

Fonte: GOOGLE MAPS (2016).

Figura 2 - Mapa da localização de Manguinhos (Serra-ES)

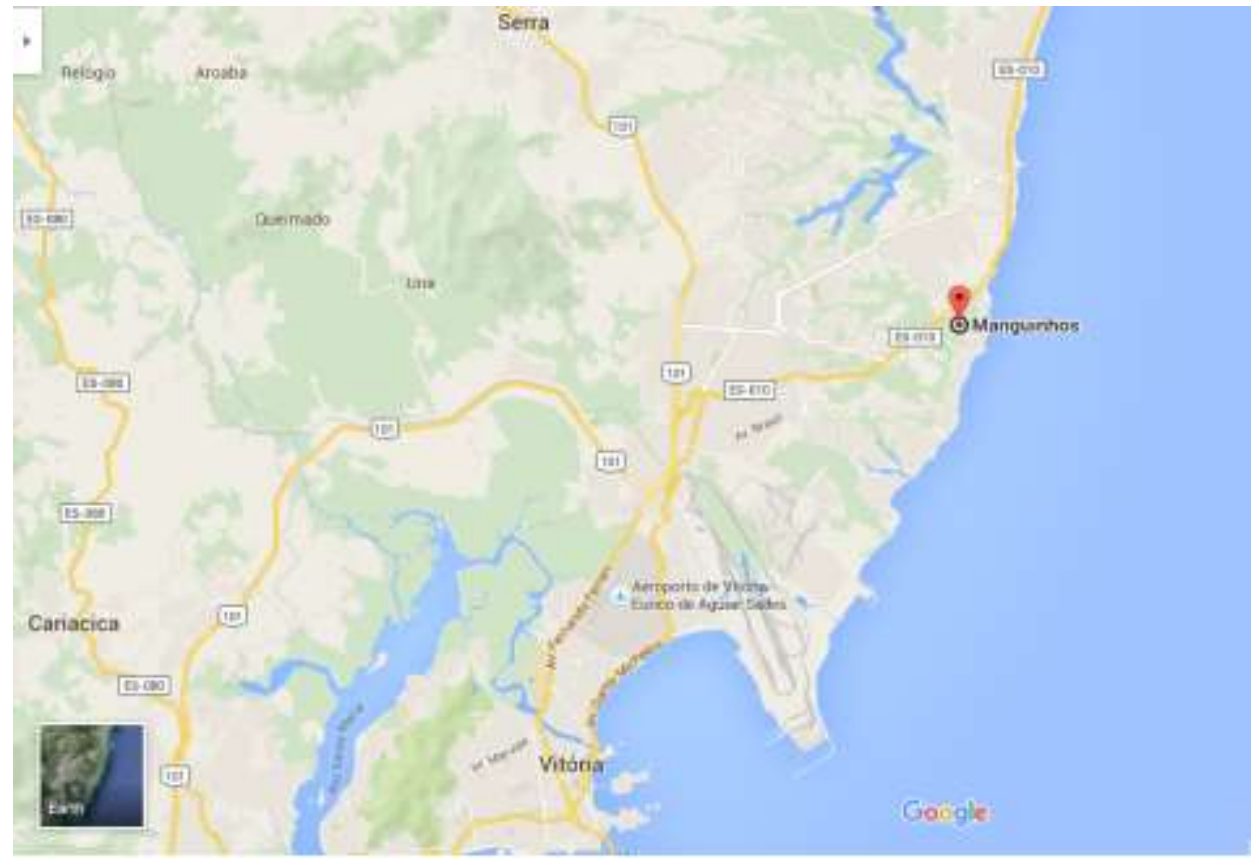

Fonte: GOOGLE MAPS (2016). 


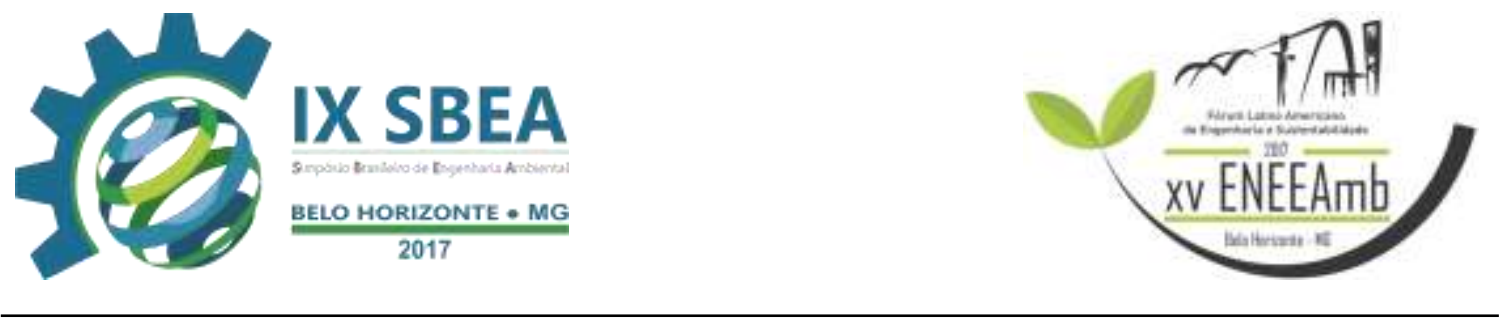

\subsection{MONTAGEM DO REATOR}

Cupons de aço inoxidável AISI 316 já polidos com dimensões de 20x50x1,8 $\mathrm{mm}$, foram limpos individualmente e secos com secador.

Os experimentos foram conduzidos no Laboratório de Biotecnologia e Sustentabilidade (LABIOTECS) do Ifes - Campus Vitória, por 40 dias, em dois sistemas estáticos abertos (biorreatores) com capacidade de $15 \mathrm{~L}$ cada com 10 cupons cada. Foi feita a renovação semanal da água do mar para simular o ambiente natural. Os cupons de aço foram suspensos no estilo varal de modo a ficarem imersos na água contida no biorreator. A água do biorreator foi circulada com bombinhas de aquário para uma melhor oxigenação (figura 3).

Figura 3 - Cupons de aço imersos em biorreatores contendo água do mar

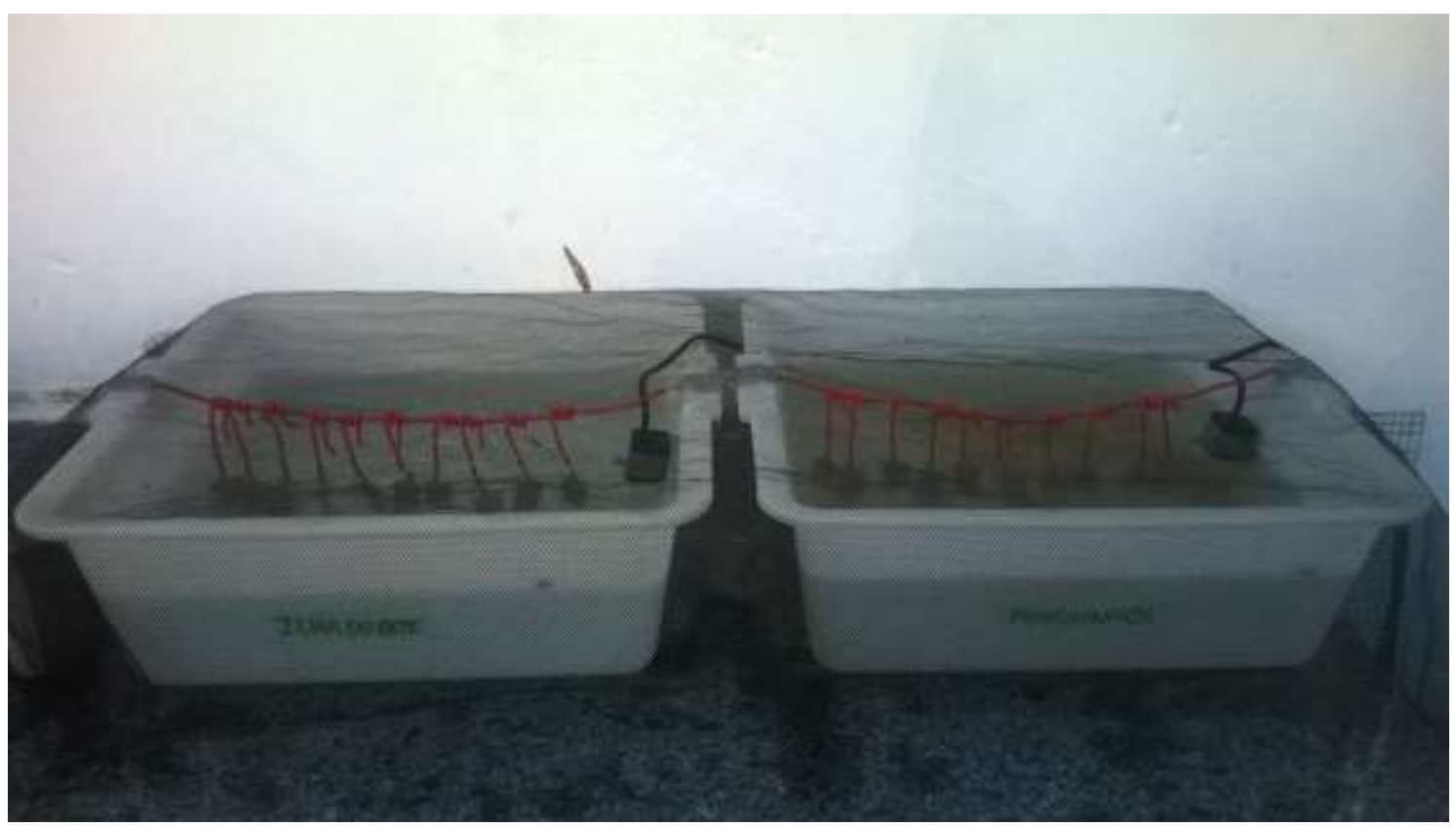

Fonte: AUTORIA PRÓPRIA (2016).

\subsection{ANÁLISES MICROBIOLÓGICAS}

As análises microbiológicas consistiram em enumeração de Unidades Formadoras de Colônias $/ \mathrm{cm}^{2} \quad\left(\mathrm{UFC} / \mathrm{cm}^{2}\right)$, caracterização morfológica dos microrganismos e determinação de coliformes totais e Escherichia coli. 


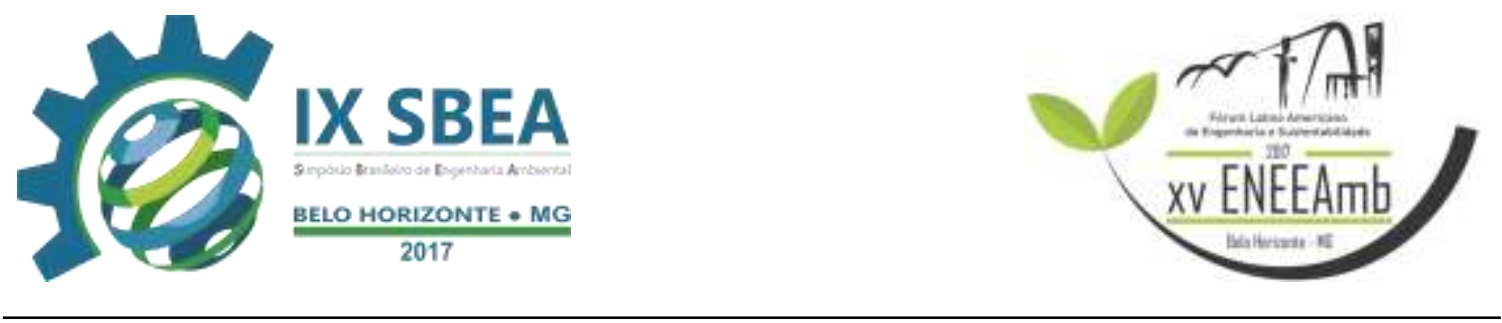

Após o período de imersão de 40 dias nos reatores contendo água do mar, os corpos de prova foram retirados com pinça esterilizada, lavados delicadamente em água esterilizada para a retirada de células não aderidas. A coleta do material aderido nos cupons foi realizada em triplicata e com o uso de três swabs esterilizados. Então foi feita e enumeração de $\mathrm{UFC} / \mathrm{cm}^{2}$. Culturas isoladas foram obtidas a partir das placas de $\mathrm{UFC} / \mathrm{cm}^{2}$ e as lâminas preparadas pela técnica da coloração diferencial de Gram com objetivo de caracterizar morfologicamente os isolados.

Também avaliou-se a qualidade microbiológica da água do reator após os 40 dias de estudo utilizando-se o método de presença ou ausência de coliformes totais e Escherichia coli através do uso de substrato cromogênico, preconizado pelo Standard Methods of the Examination of Water and Wastewater (APHA/AWWA/WEF, 2005).

\subsection{TAXA DE CORROSÃO}

A determinação da taxa de corrosão dos cupons de aço foi feita pelo método da massa de referência onde os cupons de aço AISI 316 foram pesados em balança de precisão (modelo AL 500 Marte) antes do início do experimento e após os 40 dias de imersão em água do mar, com a retirada do biofilme e com o tratamento apropriado (DECAPAGEM). A determinação foi feita em triplicata das amostras e posteriormente foi calculada a média.

Como a perda de massa é influenciada pela área exposta e tempo de exposição, essas variáveis foram combinadas e expressas em taxa de corrosão (FERREIRA et al., 2002). De acordo com Associação Brasileira de Corrosão (2013) os valores das taxas de corrosão podem ser expressos pela redução de espessura do material por unidades de tempo (em mm/ano) e/ou pela perda de massa por unidade de área, por unidade de tempo em $\mathrm{mg} / \mathrm{dm} 2 / \mathrm{dia}$ (mdd).

\section{RESULTADOS E DISCUSSÃO}

\subsection{ANÁLISES MICROBIOLÓGICAS}

\subsubsection{Unidades Formadoras de Colônias $/ \mathrm{cm}^{2}\left(\mathrm{UFC} / \mathrm{cm}^{2}\right)$}




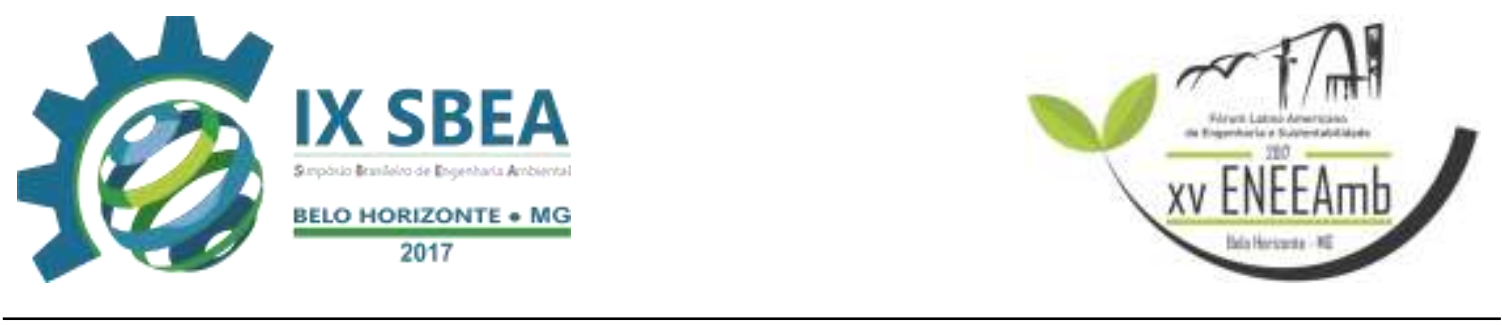

A tabela 1 mostra o número de $\mathrm{UFC} / \mathrm{cm}^{2}$ obtida a partir dos cupons de aço imersos por 40 dias em água das praias de Manguinhos e Ilha do Boi. Foram feitas contagem global de microrganismos aeróbios mesófilos heterotróficos e a contagem de bolores e leveduras.

Tabela 1 - Número de Unidades Formadoras de Colônias por $\mathrm{cm}^{2}$ nos cupons de aço 316 imersos

\begin{tabular}{|c|c|c|}
\hline $\begin{array}{c}\text { Fonte de } \\
\text { Água }\end{array}$ & $\begin{array}{c}\text { Contagem Global de Microrganismos } \\
\text { Aeróbios Mesófilos Heterotróficos (em } \\
\left.\text { UFC } / \mathrm{cm}^{2}\right)^{*}\end{array}$ & 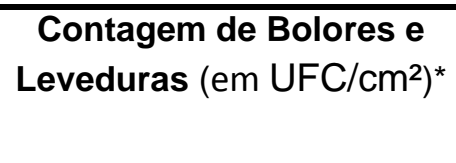 \\
\hline Ilha do Boi & $2,5.10^{2}$ & $4,0.10^{2}$ \\
\hline Manguinhos & $3,5.10^{2}$ & $2,0.10^{2}$ \\
\hline
\end{tabular}

${ }^{\star} A$ contagem foi feita com menos de 30 colônias

Fonte: AUTORIA PRÓPRIA (2016).

De acordo com número de $\mathrm{UFC} / \mathrm{cm}^{2}$ constatou-se um número maior na contagem global de microrganismos aeróbios mesófilos heterotróficos em Manguinhos comparado com a Ilha do Boi. Este resultado pode estar relacionado ao fato de que em Manguinhos a diversidade de microrganismos ter sido maior no que refere à classificação morfológica. Como por exemplo as Cianobactérias que foram isoladas na água de Manguinhos e ausentes na Ilha do Boi.

Quanto à contagem de bolores e leveduras, observou-se um número maior na Ilha do Boi quando comparado com Manguinhos, possivelmente pela água da Ilha do Boi ser um ambiente mais antropizado, com maior circulação de embarcações, e possivelmente por apresentar maior quantidade de matéria orgânica. Os bolores são fungos filamentosos que obtêm sua nutrição a partir de matéria orgânica disponível no ambiente e as leveduras são fungos não filamentosos que estão bem difundidos na natureza sendo disseminados principalmente pelo vento e pelas correntes aéreas (TORTORA; FUNKE; CASE, 2010). 


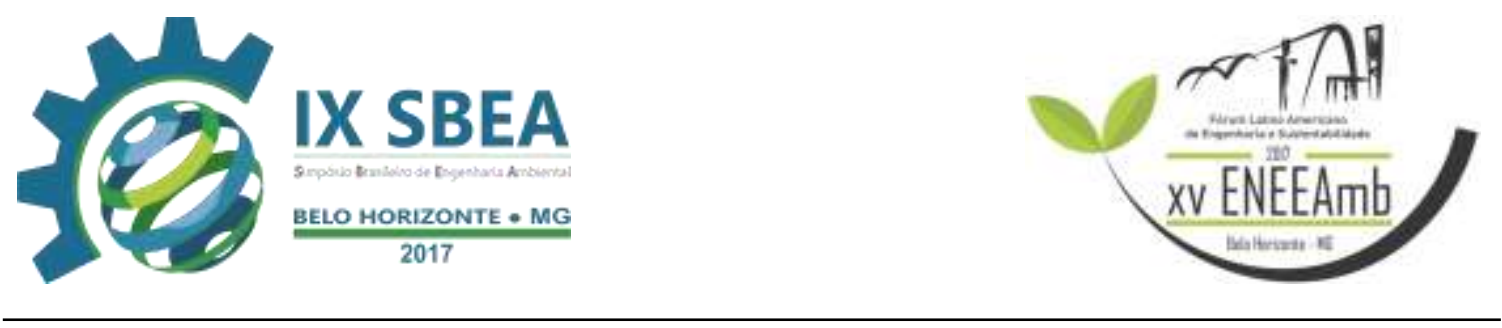

\subsubsection{Caracterização Morfológica}

A caracterização morfológica dos isolados microbianos permitiu avaliar a forma, o arranjo e a reação à técnica de coloração diferencial de Gram. Foi possível observar estreptobacilos Gram positivos, estafilococos Gram positivos e bacilos Gram negativos como morfotipos microbianos da Ilha do Boi. Como morfotipos microbianos isolados da superfície do aço imerso em água da praia de Manguinhos, estafilococos Gram positivos, bacilos e diplobacilos Gram positivos, bacilos finos Gram negativos e dois tipos de cianobactérias.

Pedrós-Alió e Brock (1983) afirmaram que a disponibilidade de substrato, a força de corrente ou fluxo da água do sistema e a alimentação pelo zooplâncton são variáveis que podem influenciar na disponibilidade das bactérias na água em ambientes naturais.

No presente trabalho, a troca semanal da água e a circulação da água simulando o ambiente natural, influenciaram na diversidade de microrganismos. Essa diversidade foi encontrada principalmente nos cupons imersos na água de Manguinhos.

A caracterização morfológica mostrou a presença de cianobactérias somente nos aços imersos na água de Manguinhos. Estas estiveram ausentes na Ilha do Boi possivelmente pelo predomínio de fungos na superfície do aço imerso em água desse ambiente.

\subsubsection{Coliformes Totais e Escherichia coli}

Os resultados não apresentaram fluorescência azul sob luz ultravioleta para ambos ambientes (Ilha do Boi e Manguinhos), o que indica ausência de Escherichia coli nas amostras. Escherichia coli é o indicador da contaminação fecal de ambientes, o que significa que, quando detectada, indica a presença de patógenos.

Mesmo a caracterização morfológica indicando bacilos Gram negativos nos aços imersos na água de Manguinhos e bacilos finos Gram negativos nos aços imersos na água da Ilha do Boi, os resultados indicaram ausência de Escherichia coli, portanto ausência de patógenos nos dois ambientes. 


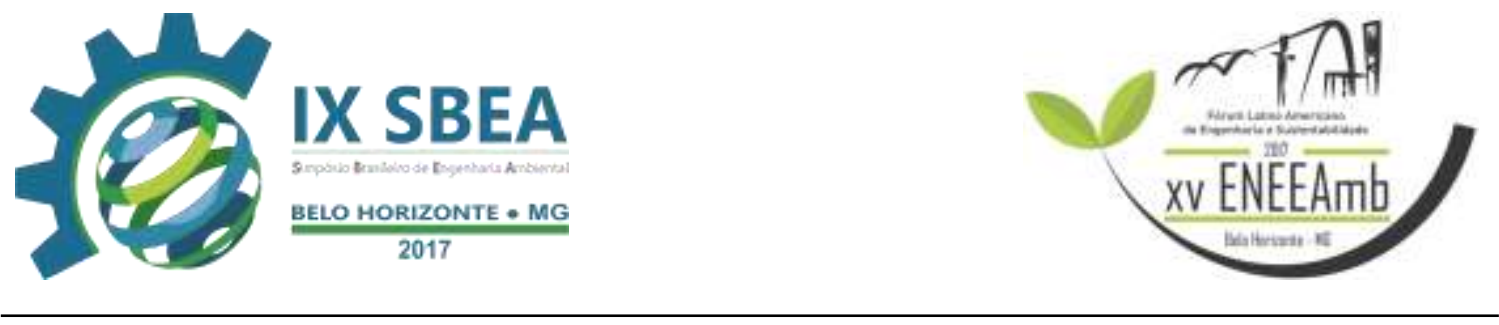

\subsection{TAXA DE CORROSAO}

O cálculo da taxa de corrosão pela perda de massa dos cupons de aço indica que a taxa de corrosão foi cinco vezes maior nas amostras imersas nos reatores com a água de Manguinhos. A tabela 2 mostra as taxas de corrosão dos cupons de aço, considerando a redução da espessura do material (mm/ano) e a perda de massa em $\operatorname{MDD}\left(\mathrm{mg} / \mathrm{dm}^{2} / \mathrm{dia}\right)$.

Tabela 2 - Cálculo da taxa de corrosão pela perda de massa dos cupons de aços AISI 316 imersos por 40 dias nas águas de Manguinhos e da Ilha do Boi

\begin{tabular}{|c|c|c|c|c|c|c|}
\hline & M1 (g) & M2 (g) & M3 (g) & Média (g) & $\begin{array}{c}\text { Taxa de corrosão } \\
\text { (mm/ano) }\end{array}$ & $\begin{array}{c}\text { Taxa de } \\
\text { corrosão } \\
\left(\mathrm{mdd} / \mathrm{dm}^{2} / \mathrm{dia}\right)\end{array}$ \\
\hline Ilha $_{i}$ & 11.957 & 11.891 & 12.248 & & & \\
\hline Ilha $_{\mathrm{f}}$ & 11.943 & 11.887 & 12.234 & & & \\
\hline$\Delta \mathbf{m}$ & 14 & 4 & 14 & 10 & 0,01147 & 2,5 \\
\hline Manguinhos i & 12.190 & 12.490 & 12.066 & & & \\
\hline Manguinhos $_{f}$ & 12.157 & 12.405 & 12.040 & & & \\
\hline$\Delta \mathbf{m}$ & 33 & 85 & 34 & 50 & 0,05738 & 12,5 \\
\hline
\end{tabular}

Fonte: AUTORIA PRÓPRIA (2016).

Araujo (2011) constatou que a corrosão pode ser atribuída especificamente à formação de biofilmes e à atividade dos microrganismos neles presentes, por vários mecanismos como, por exemplo, pela geração de agentes corrosivos, ácidos orgânicos e inorgânicos.

\section{CONCLUSÕES/RECOMENDAÇÕES}

$\mathrm{O}$ número de $\mathrm{UFC} / \mathrm{cm}^{2}$ mostrou maior contagem global de microrganismos aeróbios mesófilos heterotróficos em Manguinhos (3,5×10²) e uma maior contagem de bolores e leveduras na Ilha do Boi $\left(4,0 \times 10^{2}\right)$.

Pela caracterização morfológica dos microrganismos presentes na superfície dos aços imersos na água da praia de Manguinhos e da Ilha do Boi, observou-se que a troca 


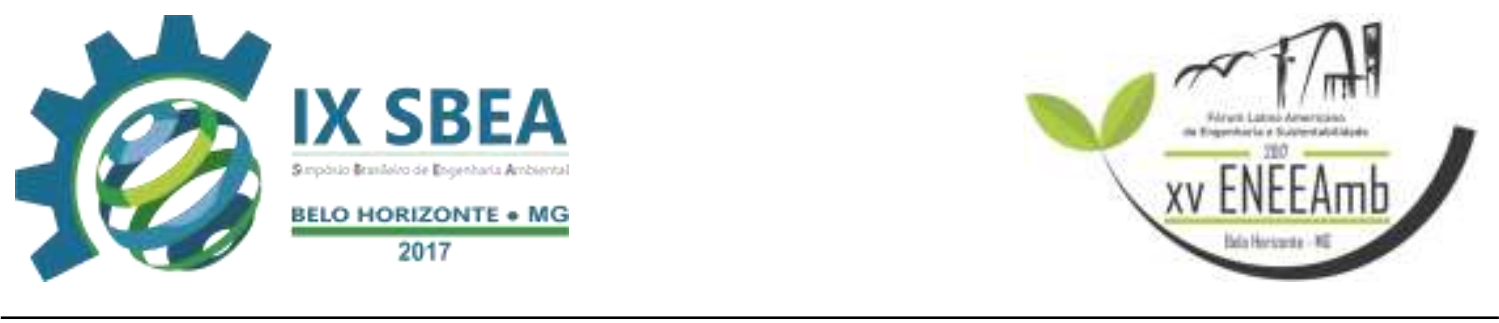

semanal da água e a circulação da mesma simulando o ambiente natural, influenciaram na diversidade de microrganismos não encontrados em trabalhos desenvolvidos anteriormente. E que foi possível observar a presença de cianobactérias somente nos aços imersos na água de Manguinhos, possivelmente pelo predomínio de fungos na superfície dos aços imersos na água de Ilha do Boi.

Mesmo a caracterização morfológica indicando bacilos Gram negativos nos aços imersos na água de Manguinhos e bacilos finos Gram negativos nos aços imersos na água da Ilha do Boi, os resultados indicaram ausência de Escherichia coli, portanto ausência de patógenos nos dois ambientes, após 40 dias de experimento.

Mostrou-se um processo corrosivo maior no aço com o biofilme de Manguinhos quando comparado ao da Ilha do Boi, na qual a taxa de corrosão por perda de massa foi cinco vezes maior nas amostras imersas em água de Manguinhos.

O estudo de biofilme no aço inoxidável em ambientes marinhos se torna importante principalmente na área de Engenharia Sanitária e Ambiental devido a dinâmica de formação e interação dos mesmo com o meio de estudo, podendo comprometer a balneabilidade da água do mar como o descarte indevido do material danificado pela corrosão gerando um grande acúmulo de sucata.

\section{REFERÊNCIAS BIBLIOGRÁFICAS}

\section{APHA/AWWA/WEF. Standard Methods for the Examination of Water and}

Wastewater. 21.ed.Baltimore/Maryland: Port City Press/American Public Health Association, 2005.

ARAUJO, L. C. A. Avaliação da Corrosão Induzida Microbiologicamente em Aço Carbono AISI 1020 Revestido com Tinta Pigmentada com Óxido de Nióbio. 2011. 127f. Dissertação (Mestrado em Ciências) - Pós-graduação em Tecnologia de Processos Químicos e Bioquímicos, UFRJ, Rio de Janeiro, 2011.

ASSOCIAÇÃO BRASILEIRA DE CORROSÃO. Corrosão uma abordagem geral. Rio de Janeiro, 2013. Disponível em: http://paginapessoal.utfpr.edu.br/israel/teoria/Teoria_Corrosao_ABRACO.pdf/at_downl oad/file. Acesso: 14 jan. 2016.

FERREIRA, L. A.; CURTA, R. F. C.; ALBERTI, S. M.; ZDEBSKY, S. R. Química Aplicada - Corrosão. Equipe Petrobras / Abastecimento. p.1-30 Curitiba, 2002. 


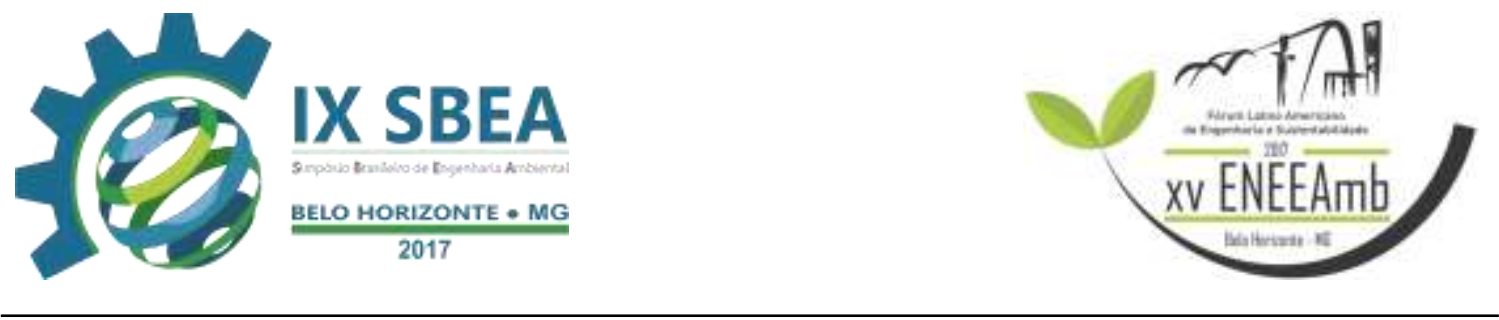

GOOGLE MAPS. Mapa da Ilha do Boi, Vitória, ES. Disponível em:

https://www.google.com.br/maps/search/Ilha+do+Boi,+Vit\%C3\%B3ria++Esp\%C3\%A Drito+Santo/@-20.3005004,-40.3022264,14z. Acesso: 7 jan. 2016

GOOGLE MAPS. Mapa de Manquinhos, Serra, ES. Disponível em:

https://www.google.com.br/maps/place/Hotel+Ilha+do+Boi/@-20.3103237,-40.3004557,14z/data $=! 4 \mathrm{~m} 2 ! 3 \mathrm{~m} 1$ !1s0xb817bb8cbb8f7f:0xe42395a325a9f7f2 . Acesso: 7 jan. 2016.

MELLO, I. S.; ÁVILA, J. S.; SILVA, S. A. Utilização da Fluoresceína como Inibidor de Corrosão. Revista Liberato, v. 16, n. 25, p. 66-72, Novo Hamburgo, 2015.

MENEZES, D. L. F. Avaliação de Biofilme e Produtos de Corrosão sobre Aço Carbono SAE 1005, em Ambiente Marinho. 2012. 183f. Dissertação (Doutorado em Tecnologia de Processos Químicos e Bioquímicos) - Universidade Federal do Rio de Janeiro, Rio de Janeiro, 2012.

PEDRÓS-ALIÓ, C.; BROCK, T.D. The importance of attachment to particles for planktonic bacteria. Arch. Hydrobiol. 98(3) 354-376, 1983.

PONTE, H. A. Fundamentos da Corrosão. Disciplina: Eletroquímica aplicada e corrosão. TQ - 417. Departamento de Engenharia Química, UFPR, Curitiba, 2003. $112 \mathrm{p}$.

RECH, C. R.; ALIATTI, L. N. S.; BRABES, K. C. S.; NEGRÃO, F. J.; SILVA, K. E; ORTOLANI, L. G.; GOES, R. H. T. B. Adesão e Formação de Biofilme de (Tereftalato de Etileno), PET e Látex Siliconizado. In: Congresso Brasileiro de Microbiologia, Natal, RN, 2013. Disponível em: http://www.sbmicrobiologia.org.br/cd27cbm/resumos/R1759-2.html. Acesso em: 25 fev. 2016.

TORTORA, G. J.; FUNKE, B. R.; CASE, C. L. Microbiologia. 10. ed., Porto Alegre: Artmed, 2010. 